Ratu Humaemah

\title{
PERAN ZAKAT DALAM PENGEMBANGAN SEKTOR RIIL
}

\begin{abstract}
Abstrak
Zakat merupakan pajak yang bersifat relijius-ekonomik yang diwajibkan kepada muzakki oleh negara untuk dialokasikan kepada mustahik seperti yang telah ditetapkan dalam Al-Quran.

Zakat yang juga merupakan kewajiban umat muslim dapat digunakan sebagai upaya pemerataan kekayaan. Hal ini dilihat dari banyaknya jenis-jenis zakat, penggunaanya bisa saja dikembangkan untuk sektor riil. Penekanan selanjutnya bagaimana umat Islam sendiri mempunyai keinginan yang kuat untuk menerapkan sistem ini, dan bagaimana pengelolaannya agar dapat tersalurkan merata sehingga tujuan dapat tercapai.

Diantara cara meningkatkan penghasilan mustahik/kaum dhuafa, adalah pendistribusian zakat yang dilakukan dengan memberikan bantuan modal usaha bagi para mustahiq/kaum dhuafa. Karena salah satu sektor yang perlu mendapat perhatian dan dukungan adalah sektor riil. Adapun pengusaha besar, mereka memiliki akses modal dari banyak elemen.

Sektor riil memiliki peran yang sangat besar dalam menyerap angka pengangguran, serta meningkatkan pertumbuhan ekonomi dan kesejahteraan masyarakat. Selain itu, kinerja sektor ini pun mempengaruhi kinerja sektor keuangan/moneter.
\end{abstract}

Kata Kunci: Zakat, sektor riil.

\section{Pendahuluan}

Zakat merupakan salah satu dari lima pilar Islam, dimana zakat memiliki pengaruh langsung bukan hanya kepada hubungan manusia dengan Allah SWT (hablunminallah) sebagai Pencipta, tetapi juga kepada hubungan antara manusia dengan masyarakat (hablunminannaas). Kewajiban membayar zakat dapat dijadikan sebagai parameter ketaatan manusia kepada Allah SWT, dan juga dapat digunakan sebagai pemerataan kekayaan antara yang kaya dan yang miskin.

Sejak Islam datang ke Indonesia zakat telah memainkan peran penting sebagai elemen penunjang dakwah dan pembangunan masyarakat. Zakat merupakan pranata keagamaan yang memiliki kaitan secara fungsional dengan upaya pemecahan masalah kemiskinan dan kepincangan sosial. Dana umat Islam yang terkumpul dari zakat merupakan potensi besar yang dapat didayagunakan bagi upaya menyelamatkan 
nasib puluhan juta rakyat miskin di Indonesia yang belum dilindungi oleh sistem jaminan sosial yang terprogram dengan baik.

Sejarah peradaban Islam telah mencatat dan membuktikan bahwa penerapan konsep zakat telah mampu memberikan kesejahteraan dan kemakmuran kepada masyarakat. Hal ini dimulai dari Khalifah Abu Bakar Shiddiq, yang bersikap sangat tegas terhadap orang-orang yang tidak mau membayar zakat. Paling fenomenal adalah kisah sukses Khalifah Umar Bin Abdul Aziz, hanya dalam waktu kurang lebih dua tahun, dengan konsep zakat mampu menyejahterakan rakyatnya yang tengah dilanda krisis pada saat itu.

Jika zakat dikelola dengan baik, profesional, dan transparan dengan sistem dan manajemen yang amanah, profesional dan integrated, di bawah bimbingan dan pengawasan dari pemerintah dan masyarakat, akan menjadi pemacu gerak ekonomi di dalam masyarakat dan menyehatkan tatanan sosial sehingga makin berkurangnya kesenjangan antara kelompok masyarakat yang mampu dan kelompok masyarakat yang tidak mampu. Selain itu, zakat juga dapat mengatasi persoalan ekonomi umat pada saat ini, sehingga nantinya akan tercipta keadilan, kesejahteraan dan kemakmuran bagi suatu masyarakat.

Al-Quran sendiri menjamin bahwa zakat mampu menjawab persoalan-persoalan ekonomi yang ada. Dengan adanya bukti sejarah yang menggambarkan bagaimana keunggulan zakat dalam memecahkan persoalan-persoalan ekonomi, tinggal sekarang bagaimana umat Islam sendiri mempunyai keinginan yang kuat untuk menerapkan sistem ini, selain perlunya sosialisasi hasil kajian-kajian atau penelitian kepada masyarakat mengenai konsep Islam yang ada khususnya mengenai zakat.

Setelah lahirnya Undang-Undang RI Nomor 38 Tahun 1999 tentang Pengelolaan Zakat, maka pemerintah dalam hal ini Kementerian Agama telah melakukan berbagai upaya dalam rangka mendorong dan memfasilitasi agar pengelolaan zakat yang dilakukan Badan Amil Zakat dan Lembaga Amil Zakat dapat dilakukan secara professional, amanah dan transparan, sehingga tujuan pengelolaan zakat akan dapat tercapai.

Tulisan ini bersifat deskriptif yang menjelaskan dengan studi literatur di perpustakaan, maka masalah yang timbul adalah sejauh mana zakat dapat meningkatkan kesejahteraan masyarakat suatu negara melalui pengembangan pada sektor riil?

\section{Pengertian Zakat}

Kata "zakat" menurut bahasa berasal dari kata zaka yang berarti suci, baik, berkah, tumbuh, dan berkembang. Menurut terminologi syariah, zakat adalah nama bagi sejumlah harta tertentu yang telah mencapai syarat tertentu yang diwajibkan oleh Allah SWT untuk dikeluarkan dan diberikan kepada yang berhak menerimanya dengan persyaratan tertentu pula. Kaitan antara makna secara bahasa dan istilah ini berkaitan erat yaitu, bahwa setiap harta yang sudah dikeluarkan zakatnya akan 
menjadi suci, bersih, baik, berkah, tumbuh, dan berkembang semuanya digunakan di dalam Al- Quran dan Hadits.

Zakat dari segi istilah fikih berarti "Sejumlah harta tertentu yang diwajibkan Allah diserahkan kepada orang-orang yang berhak" disamping berarti "mengeluarkan jumlah tertentu itu sendiri." Jumlah yang dikeluarkan dari kekayaan itu di sebut zakat karena yang dikeluarkan itu menambah banyak, membuat lebih berarti dan melindungi kekayaan itu dari kebinasaan.

Setiap orang mencintai kekayaannya serta sumber-sumber kekayaan lainnya, akan tetapi orang yang menafkahkan harta untuk orang lain akan memperoleh kebajikan dan kesucian. Dalam surat At- Taubah Allah berfirman : "Ambilah zakat dari sebagian harta mereka, dengan zakat itu kamu bersihkan dan mensucikan mereka, dan mendoalah untuk mereka. Sesungguhnya do'a kamu itu menjadi ketentraman jiwa bagi mereka. Dan Allah maha mendengar lagi maha mengetahui" (9:103). Dalam sunnah, Rasulullah SAW bersabda yang diriwayatkan Bukhari dan Muslim dari Abdullah Bin Umar: "Islam dibangun atas lima rukun: Syahadat tiada Tuhan selain Allah dan Muhammad itu utusan Allah, mendirikan shalat, membayar zakat, puasa Ramadhan, dan menunaikan haji". Ijma': "Ulama baik salaf (terdahulu) maupun Khalaf (kontemporer) telah sepakat akan kewajiban zakat dan bagi yang mengingkarinya berarti telah kafir dari Islam".

Zakat menunjukkan bahwa harta kekayaan yang tidak dibelanjakan dengan cara bijaksana atas diri seseorang atau orang lain akan melahirkan kejahatan (bermewahmewah serta menciptakan persaingan dan pertarungan antar kelas) dalam masyarakat. Apabila harta kekayaan dibelanjakan untuk hal-hal yang baik, kelak dapat menumbuhkan dan mensucikan masyarakat dari kejahatan-kejahatannya. Dalam surat Al- Baqarah Allah berfirman:

"(Umpama) orang-orang yang menafkahkan hartanya, karena mengharapkan keridlaan Allah dan menetapkan (keimanan) hatinya." $(2: 265)$.

Dalam surat Al- Maidah Allah berfirman:

"Sesungguhnya penolong kamu hanyalah Allah, Rasul-Nya dan orangorang yang beriman, yang mendirikan Shalat dan menunaikan zakat serta mereka tunduk kepada Allah."(5: 55).

Tindakan mereka yang menafkahkan hartanya untuk kebaikan telah ditunjukkan dalam ayat Al- Quran sebagai menafkahkan harta kekayaan demi memperoleh keridlaan Allah, memperkuat jiwa mereka dan sebagai ketundukannya kepada Allah. Ini dengan jelas memberikan indikasi bahwa harta yang yang dinafkahkan demi kebaikan orang banyak tanpa mengharapkan suatu imbalan apapun, mempunyai arti yang sangat signifikan. Sesungguhnya, zakat dinamakan demikian karena ia dapat membantu mensucikan jiwa manusia dari sifat keakuan, kekikiran dan cinta akan harta. Di dalam Al-Quran Surat al-'Ala Allah berfirman : 
"Sesungguhnya beruntunglah orang-orang yang menyucikan diri/ membersihkan diri." (87: 14).

Dalam surat As-Syam Allah berfirman:

"Sesungguhnya beruntunglah orang yang menyucikan jiwanya, dan sesungguhnya merugilah orang yang mengotorinya." (91:9-10).

\section{Macam-Macam Harta Yang Wajib Dizakatkan}

Sebelum membahas macam-macam harta yang wajib zakat, perlu dijelaskan persyaratan harta yang wajib dizakatkan dan siapa saja orang-orang yang berhak menerima zakat tersebut. Syarat-syarat harta yang wajib zakat terdiri dari:

1. Harta itu dikuasai secara penuh dan dimiliki secara sah, yang didapat dari usaha, bekerja, warisan, atau pemberian yang sah, dimungkinkan untuk dipergunakan, diambil manfaatnya, atau kemudian disimpan.

2. Harta yang berkembang jika diusahakan atau memilliki potensi untuk berkembang. Misalnya harta perdagangan, peternakan, pertanian, deposito mudharabah, usaha bersama, obligasi, dan lain sebagainya.

3. Telah mencapai nishab, harta itu telah mencapai ukuran tertentu. Misalnya untuk hasil pertanian telah mencapai jumlah $653 \mathrm{~kg}$. Emas atau perak telah senilai 85 gram, perdangangan telah mencapai 85 gram emas, peternakan sapi telah mencapai 30 ekor dan lain sebagainya.

4. Telah melebihi kebutuhan pokok, yaitu kebutuhan minimal yang diperlukan seseorang dan keluarganya yang menjadi tanggungannya untuk kelangsungan hidupnya.

5. Telah mencapai satu tahun untuk harta-harta tertentu. Misalnya perdagangan. Akan tetapi untuk tanaman dikeluarkan zakatnya pada saat memanennya (AlAn'am:141), begitu jugu rikaz dan barang tambang.

Orang yang berhak menerima zakat telah ditentukan oleh Al Quran surat At Taubah :

"Sesungguhnya zakat itu untuk orang-orang fakir, orang-orang miskin, pengurus zakat, muallaf yang dibujuk hatinya, untuk memerdekakan hamba (budak), orang yang berhutang, untuk jalan Allah dan untuk para musafir, sebagai sesuatu ketetapan yang diwajibkan Allah". (9:60).

1. Fakir : adalah orang yang tidak memiliki harta atau penghasilan yang layak untuk memenuhi keperluan sehari-hari. Misalnya orang yang kebutuhannya Rp. 1 juta sebulan tetapi yang ada hanya Rp. 400 ribu atau kurang.

2. Miskin: adalah mereka yang mempunyai harta atau penghasilan layak dalam memenuhi keperluan diri dan keluarganya tetapi tidak sepenuhnya tercukupi. Misalnya kebutuhan yang dibutuhkan Rp. 1 juta tetapi yang ada hanya Rp. 700 ribu. 
3. Muallaf: adalah kelompok yang ingin dijinakkan hatinya supaya cenderung kepada Islam atau mengokohkan keIslamannya atau dapat menghindari dari kejahatannya atau kelompok yang diharapkan manfaatnya dalam menolong umat Islam terhadap musuhnya.

4. Fir Riqaab: adalah jama' dari kata raqabah yaitu budak laki-laki tetapi yang dimaksud adalah budak lelaki dan perempuan. Fir Riqaab artinya mengeluarkan zakat untuk memerdekakan budak, sehingga terbebas dari dunia perbudakan.

5. Ghariimin: adalah orang yang mempunyai hutang dan dia tidak mempunyai harta yang lebih dari hutangnya.

6. Fi Sabilillah: adalah jihad di jalan Allah tetapi bukan hanya pada peperangan atau jihad fisik saja, tetapi termasuk semua jihad Fi Sabilillah seperti dakwah untuk menegakkan Islam, membebaskan manusia dari kemusyrikan dan lain-lain.

7. Ibnu Sabil: adalah musafir yang sedang dalam perjalanan atau bepergiannya untuk kemaslahatan umat sehingga dapat dirasakan oleh umat Islam. Dapat juga dikatakan orang yang hendak bepergian yang tidak mempunyai bekal, tetapi dengan syarat bukan untuk maksiat.

8. Amilin: adalah orang-orang yang terlibat dalam kepanitiaan zakat, seperti petugas-petugas yang mengambil zakat dari mustahikin, pencatat, petugas yang menyalurkan zakat.

Jenis zakat ada dua macam yaitu zakat harta dan zakat fitrah (diri). Zakat harta dibaagi menjadi:

\section{Zakat Uang, Emas dan Perak dan Perhiasan}

Dari Ali ra. Nabi SAW bersabda: "jika kamu mempunyai 200 dirham dan sudah cukup setahun maka zakatnya adalah 5 dirham, dan emas hanya dikenakan zakat bila sudah mencapai 20 dinar dan sudah cukup setahun maka zakatnya adalah $1 / 2$ dinar. Setiap bertambah maka dengan hitungan tersebut"(HR. Abu Dawud).

Dari hadits di atas maka nisab uang baru wajib dizakati adalah 200 dirham. Sedangkan nisab emas baru wajib dizakati bila sudah mencapai 20 dinar, dimana 1 dinar $=4,25$ gram emas berarti nisab emas adalah $20 \times 4,25=85$ gram emas. Adapun nisab perak diketahui dari nisab emas. Berat perak 1 dirham $=7 / 10$ dinar, berarti 7/10 x $200=595$ gram perak. Sedangkan taif zakat emas dan perak, ulama sepakat bahwa zakatnya adalah $1 / 40$ atau $2,5 \%$ dan lama pemilikkan harta tersebut telah mencapai syarat haul (satu tahun).

Sedangkan untuk zakat Perhiasan menurut ulama Imam Abu Hanifah wajib zakat pada perhiasan emas dan perak jika sudah sampai senisab. Pendapat jumhur ulama seperti Imam Maliki, Imam Syafi 'i, dan Imam Ahmad tidak mewajibkan zakat perhiasan emas dan perak yang dipakai wanita. Karena harta tersebut tidak termasuk harta yang produktif. Adapun perhiasan yang disimpan dan berlebihan terkena wajib zakat.

\section{Zakat Profesi}


Wajibnya zakat profesi ini bersumber dari firman Allah surat Al-Baqarah ayat 267, artinya: "wahai orang-orang beriman, nafkahkanlah (keluarkanlah zakat) dari hasil usahamu yang halal dan dari apa yang kami keluarkan dari bumi untuk kamu”.

Arti harta profesi adalah harta yang diperoleh dari pemanfaatan profesi yang ada pada dirinya dengan berbagai macam upaya yang syar'I seperti hibah, upah kerja rutin, profesi dokter, aristek, pengacara.

Berkaitan dengan masalah haul dalam wajib zakat, para ulama berbeda pendapat. Pendapat Syafi'i dan Ahmad mensyaratkan adanya haul terhitung dari kekayaan itu didapat. Pendapat Abu Hanifah, Malik dan ulama modern seperti Muh. Abu Zahrah, Abdul Wahab Khalaf. Mensyaratkan haul tetapi terhitung dari awal dan akhir harta itu diperoleh pada tahun tersebut. Jika sampai nisabnya maka dikeluarkan zakatnya. Pendapat Ibnu Abbas, Ibnu Mas`ud, ulama bin Abdul Aziz dan ulama modern seperti Yusuf Qardhawi tidak mensyaratkan haul, zakat dikeluarkan langsung ketika mendapatkan harta tersebut. Mereka mengqiyaskan dengan zakat hasil pertanian.

Menurut penulis bentuk harta yang dikeluarkan untuk zakat profesi berupa uang maka tarif yang tepat adalah tarif zakat emas atau perdagangan yaitu sebesar 2,5\%.

\section{Zakat Binatang Ternak}

Dalilnya bersumber dari hadis Riwayat Bukhari dari Anas bin Malik. Jenis binatang, misalnya unta, nisab dan zakatnya antara lain:

\begin{tabular}{|c|l|}
\hline Nisab Unta & \multicolumn{1}{|c|}{ Banyak zakat yang wajib dikeluarkan } \\
\hline Dari - sampai: & Seekor kambing \\
$5-9$ & 1 ekor kambing \\
$10-14$ & 2 ekor kambing \\
$15-19$ & 3 ekor kambing \\
$20-24$ & Seekor anak unta betina (berumur 1 tahun lebih) \\
$25-35$ & Seekor anak unta betina (berumur 2 tahun lebih) \\
$36-45$ & Seekor anak unta betina (berumur 3 tahun lebih) \\
$46-60$ & Seekor anak unta betina (berumur 4 tahun lebih) \\
$61-75$ & 2 ekor anak unta betina (berumur 2 tahun lebih) \\
$76-90$ & 2 ekor anak unta betina (berumur 3 tahun lebih) \\
$91-120$ &
\end{tabular}

Sedangkan bila memelihara kambing, nisab dan zakatnya sebagai berikut:

\begin{tabular}{|c|c|l|}
\hline Dari & Sampai & \multicolumn{1}{|c|}{ Kadar Kewajiban Zakat } \\
\hline 1 & 39 & Tidak ada zakatnya \\
40 & 120 & 1 ekor kambing \\
121 & 200 & 2 ekor kambing \\
\hline
\end{tabular}




\begin{tabular}{|c|c|l|}
\hline Dari & Sampai & \multicolumn{1}{|c|}{ Kadar Kewajiban Zakat } \\
\hline 201 & 399 & 3 ekor kambing \\
400 & 499 & 4 ekor kambing \\
500 & 599 & 5 ekor kambing \\
\hline
\end{tabular}

Untuk hewan sapi, nisab dan zakatnya adalah setiap 30-39 ekor maka zakatnya 1 ekor sapi tabi`atau tabi ah, 40-59 ekor maka zakatnya 2 ekor sapi tabi atau tabi ah, 70-79 ekor maka zakatnya 2 ekor sapi musinnah dan satu tabi’.

\section{Zakat Pertanian Dan Hasil Bumi}

Firman Allah SWT: "...Makanlah dari buahnya bila dia berbuah, dan tunaikanlah haknya di hari memetik hasilnya (dengan disedekahkan kepada fakir miskin), dan jangan kamu berlebih-lebihan. Sesengguhnya Allah tidak menyukai orang yang berlebih-lebihan" (QS:6:141).

HR Muslim, dari jabir ra, Rasulullah SAW bersabda: “...tidak wajib zakat pada kurma yang kurang dari 5 ausuq".

Nisab hasil pertanian adalah 5 wasaq yang menurut ukuran sekarang adalah $652,8 \mathrm{~kg}$ makanan pokok (gabah) digenapkan $653 \mathrm{~kg}$. Jika diukur dengan menggunakan beras menjadi $520 \mathrm{~kg}$.

Sedangkan besar wajib zakat yang harus dikeluarkan ada dua kategori:

a) Jika diairi secara alamiah maka zakatnya $1 / 10$ atau $10 \%$.

b) Jika diairi dengan menggunakan alat bantu maka zakatnya $1 / 20$ atau 5\%

Berbeda dengan zakat perternakan, zakat pertanian menggunakan sistem flat rate, dengan pertimbangan bila hasil pertanian merupakan barang yang tidak tahan lama (non-durable), dikhawatirkan akan busuk bila hasil panen melimpah. Yang menjadi pembedanya adalah jenis pengairan yang dipergunakan.

Zakat tidak berpengaruh terhadap penawaran agregatif (AS) secara mikro, karena zakat diterapkan dalam bentuk quasi rent, bukan dalam bentuk value added tax (pajak pertambahan nilai). Dengan memaksimumkan zakat, quasi rent dan tingkat keuntungan juga akan maksimum. Zakat merupakan bagian kecil-kecil profit, seperti terlihat pada ilustrasi grafik berikut (asumsi perfect competition market).

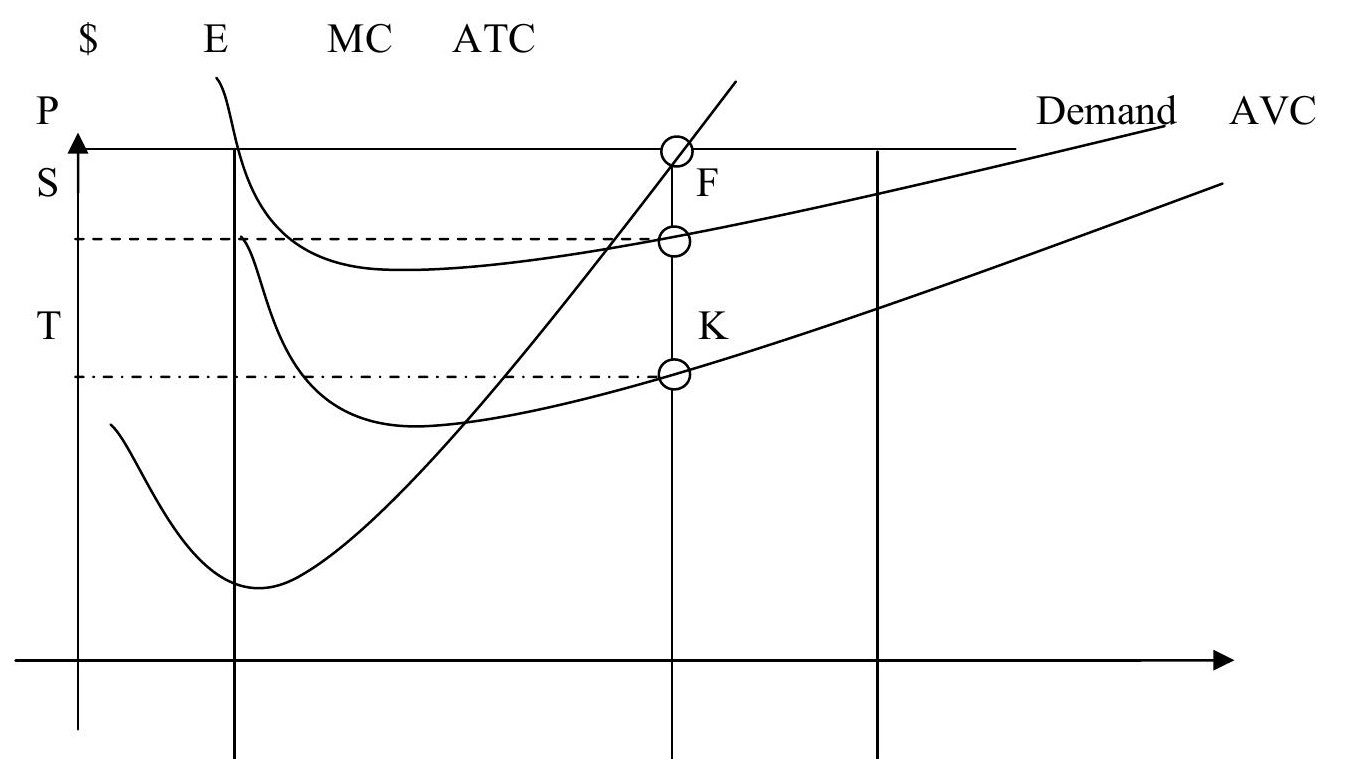



$\mathrm{O}$
$\mathrm{Q}_{1}$
$\mathrm{Q}_{2}$
$\mathrm{Q}_{3}$

B

C

Q

$\mathrm{O} \quad \mathrm{Q}_{1}$

$\mathrm{Q}_{2}$

$\mathrm{Q}_{3}$

\section{Zakat Perdagangan, Investasi dan Saham}

Kriteria dan ketentuan zakat perdagangan:

1) Dikenakan atas modal yang diputar ditambah keuntungan, piutang yang dapat dicairkan dan dikurangi hutang dan kerugian. Sarana dan peralatan yang tidak diperjualbelikan bukan termasuk harta perdangan.

2) Berjalan satu tahun.

3) Nisab zakat perdagangan sama dengan nisbah emas dan perak yaitu 20 dinar atau sekitar 85 gram emas murni. Dan tarif yang dikeluarkan 2,5\%.

4) Dapat dibayar dengan uang atau barang.

5) Dikenakan pada perdagangan sendiri maupun perseorangan.

Zakat investasi adalah zakat yang dikenakan terhadap harta yang diperoleh dari hasil investasi. Diantara bentuk usaha yang masuk investasi adalah bangunan atau kantor yang disewakan, saham, rental mobil, rumah kontrakan, investasi pada ternak atau tambak. Tiga pendapat dalam zakat investasi:

a) Ulama yang menganalogikan ke dalam zakat perdagangan sehingga zakat dikeluarkan setiap tahun dengan nisbah 85 gram dan tarif zakatnya 2,5\% dikenakan tehadap modal dan keuntungan.

b) Memasukkan ke dalam zakat uang tapi diambil dari hasilnya saja dan dikeluarkan pada saat menerimanya tanpa mensyaratkan haul. 
c) Menganalogikan ke dalam zakat pertanian, pada saat menghasilkan sedangkan modal tidak dikenakan zakat dan tarifnya $5 \%$ atau $10 \%$.

Saham adalah hak pemilikan tertentu atas kekayaan satu perseorangan terbatas atau atas penunjukan atas saham tersebut. Obligasi adalah perjanjian tertulis dari bank, perusahaan, atau pemerintah kepada bawahannya untuk melunasi sejumlah pinjaman dalam masa tertentu dengan bunga tertentu pula.

Yusuf Qaradhawi berpendapat bahwa bagi perusahaan industri (perusahaan yang modalnya terletak dalam perlengkapan, peralatan, gedung, pabrik, hotel) tidaklah dipungut zakatnya dari sahamnya tapi dari keuntungan bersihnya sebesar $10 \%$. Tetapi perusahaan dagang zakatnya dipungut berdasarkan sahamnya yaitu sebesar 2,5\% tidak termasuk nilai peralatan di dalamnya.

\section{Zakat Rikaz Dan Barang Tambang}

Jumhur ulama berpendapat bahwa rikaz adalah kekayaan yang terpendam dari peninggalan masyarakat jahiliah. Orang yang berhak menerima rikaz adalah sama dengan orang yang berhak menerima pajak, yaitu dicampur dengan anggaran negara.

Jumhur ulama sepakat bahwa besar zakat yang harus dikeluarkan pada rikaz adalah $1 / 5$ atau $20 \%$.

Sedangkan untuk barang tambang, jumhur ulama membedakan antara rikaz dan barang tambang pada besarnya zakat yang harus dikeluarkan disebabkan karena pada barang tambang beban tenaga dan biaya operasional yang besar untuk mengeksploitasi dan mengolahnya sedangkan rikaz tidak.

\section{Zakat Fitrah}

Hadis Rasulullah SAW: "Dari Ibnu Umar ra, berkata Rasulullah SAW mewajibkan zakat fitrah satu sha' kurma atau gandum pada budak, orang merdeka laki-laki atau perempuan, anak kecil dan orang dewasa dari umat Islam dan memerintahkan untuk membayarnya sebelum mereka keluar untuk Shalat Idul Fitri”.

Besar sha' menurut ukuran sekarang adalah 2,176 kg. Sedangkan makanan yang wajib dikeluarkan zakatnya adalah seperti: tepung terigu, kurma, anggur, gandum, keju. Waktu dibayarkannya zakat fitrah, menurut jumhur ulama adalah sebelum salat Id atau sebelum bulan Syawal tiba.

Zakat adalah hak yang ditentukan oleh Allah, sebagai pembuat syariat Dia-lah yang menentukan batas nisab bagi setiap macam benda dan membebaskan kewajiban kepada harta yang kurang senisab. Tidak dibenarkan berbuat semena-mena menyeru untuk menambah ketentuan mengenai kewajiban itu karena adanya perubahan ekonomi, sosial yang terjadi pada zaman sekarang. Berbeda dengan pajak yang tergantung pada kebijaksanaan dan ketentuan penguasa baik mengenai objek, persentase, harga dan ketentuannya, bahkan ditetapkan dan dihapuskan pajak itu tergantung pada penguasa. 


\section{Peran Zakat Dalam sektor riil}

Menurut ahli fiqih, zakat adalah hak tertentu yang diwajibkan oleh Allah SWT terhadap harta kaum muslim yang diperuntukkan bagi mereka (fakir miskin), sebagai tanda syukur atas nikmat Allah SWT dan untuk medekatkan diri kepada-Nya, serta membersihkan diri dari harta yang bukan hak

Sedangkan pajak menurut beberapa pakar adalah kewajiban yang ditetapkan terhadap wajib pajak, yang harus disetorkan pada negara sesuai dengan ketentuan, tanpa mendapat penghargaan dari negara, dan hasilnya untuk membiayai pengeluaran-pengeluaran umum di satu pihak dan untuk merealisasikan sebagian tujuan ekonomi, sosial, politik dan tujuan-tujuan lain yang ingin dicapai oleh negara.

Kedudukan zakat dapat dinilai dari faktanya bahwa ia merupakan salah satu dari lima pilar Islam. Tidak ada keraguan lagi bahwa zakat menempati satu kedudukan yang sangat penting dalam Islam yaitu kedua setelah shalat. Perintah untuk menunaikan shalat dalam Al-Quran selalu diikuti dengan kata zakat. Pada surat Al-Baqarah kaum Muslim diperintahkan untuk selalu menegakkan shalat dan menunaikan zakat dengan ungkapan sebagai berikut:

"Dirikanlah shalat dan tunaikanlah zakat. Dan apa-apa yang kamu usahakan diantara kebaikan untuk dirimu, niscaya kamu memperoleh pahala disisi Allah." (2: 110).

Dalam ayat tersebut kaum muslim dengan tegas diberitahu bahwa apa saja yang mereka belanjakan untuk mendapatkan keridhaan Allah dalam bentuk zakat tidak akan disia-siakan,bahkan akan melahirkan kebaikan dunia dan akhirat. Pembayaran zakat juga digambarkan sebagai salah satu kualitas seorang mukmin yang benar.

Adapun hikmah Zakat bagi umat Islam diantaranya:

a) Sebagai instrumen syariat Islam yang bersifat otoritatif kepada orang kaya untuk mengeluarkan sebagian hartanya kepada orang yang sangat membutuhkan agar dapat mengurangi beban hidupnya hingga terbebas dari kefakiran, hutang, kesulitan dalam perjalanan. Dan zakat juga dapat menghindari kesenjangan sosial antara kedua kelompok tersebut.

b) Sebagai pilar kerjasama antara si kaya dengan para dai dan mujahid yang sedang melakukan tugas paling utama dalam Islam, sehingga merasa tenang dalam melaksanakan tugasnya sedangkan keluarganya tidak terlantar.

c) Mengikis akhlak buruk seperti kikir, egois, dan serakah, sekaligus mengembangkan akhlak terpuji.

d) Sebagai pembersih dan pemelihara harta dari kehancuran.

e) Sebagai ungkapan rasa syukur pada Allah SWT atas nikmat yang telah diberikan.

f) Menambah pendapatan negara untuk melaksanakan proyek-proyek umat.

Zakat dan maknanya yang terkandung di dalamnya mengisyaratkan bahwa harta yang ditimbun dan dipergunakan untuk kesenangan dirinya serta tidak dikeluarkan hak yang diwajibkan Allah atasnya, akan menjadi harta yang kotor dan najis, harta tersebut akan menjadi suci bila berzakat dan untuk menghilangkan segala sifat tamak 
dan kikir juga mengisyaratkan bahwa harta yang nampaknya berkurang menurut penglihatan orang tetapi sebenarnya ia bertambah, tumbuh dan bersih dalam pandangan orang yang melihat dengan mata batinnya.

Zakat juga menyatakan bahwa kebersihan, pertumbuhan dan berkah itu bukan hanya bagi hartanya saja, tapi juga bagi manusia, yaitu bagi yang memperoleh zakat dan bagi yang membayarkan zakat. Yang memperoleh zakat akan menjadi suci dirinya dari dengki dan benci, sehingga kehidupannya tumbuh berkembang, karena keperluan diri dan keluarganya terpenuhi, adapun si pemberi zakat menjadi suci dari kotoran sifat tamak dan kikir. Dirinya menjadi suci dengan pengorbanan dan sedekah, sehingga berkahlah dirinya, keluarganya dan hartanya.

Mengenai kelestarian dan kelangsungannya, zakat merupakan kewajiban yang bersifat tetap dan terus-menerus. Ia akan berjalan terus selagi Islam dan kaum muslimin ada di muka bumi ini. Kewajiban tersebut tidak akan dapat dihapuskan oleh siapapun. Adapun pajak, tidak memiliki sifat yang tetap dan terus-menerus, baik mengenai macam, persentase, dan kadarnya. Ia akan tetap ada selagi diperlukan dan lenyap bila sudah tidak dibutuhkan lagi.

Mengenai pengeluarannya, zakat mempunyai sasaran khusus seperti yang ditetapkan Allah SWT dalam Al-Quran dan dijelaskan oleh Rasul dengan perkataan dan perbuatan. Adapun sasaran itu adalah kemanusian dan keislaman. Adapun pajak dikeluarkan untuk membiayai pengeluaran-pengeluaran umum negara, sebagaimana ditetapkan pengaturannya oleh penguasa. Zakat harus dikeluarkan melalui pos-pos yang sudah ditetapkan oleh Al-Quran. Seorang muslim wajib membayar zakatnya dengan sukarela karena mengharap diterima oleh Allah SWT.

Adapun zakat memiliki keuntungan dibanding pajak, diantaranya:

1) Penghindaran pajak merupakan masalah serius bagi pemungutan pajak modern. Setiap orang tahu bahwa banyak orang berusaha menghindari pembayaran pajak penghasilan dengan memberikan keterangan palsu. Masalah praktek curang zakat sangat kecil kemungkinannya karena sifat religio-ekonomiknya.

2) Sumber utama zakat merupakan kekayaan tertimbun dan tidak digunakan. Dipakai untuk tujuan mulia. Hanya dengan zakatlah adanya kemungkinan untuk menggali kekayaan yang tertimbun untuk dimanfaatkan bagi kesejahteraan masyarakat yang lebih besar.

3) Pemerintah tidak diperkenankan untuk membelanjakan uang yang dipungut dari zakat dengan sesuka hati.

Zakat merupakan penopang dan tambahan pemerintah dalam meringankan beban untuk menciptakan pemerataan dan pengentasan kemiskinan. Demikian pula zakat tidak menghalangi negara untuk mengadopsi ukuran-ukuran fiskal dan skema redistribusi pendapatan serta perluasan lapangan kerja dan peluang penciptaan lapangan kerja melalui bantuan modal ringan dari zakat itu sendiri.

Pengalokasian zakat tidak dibatasi dengan batasan jangka pendek. Sebagian penulis muslim ternyata lebih menekankan pada upaya pengayaan orang-orang fakir dan miskin dengan memberikan alat-alat produksi kepada mereka dan menyediakan 
modal, berbagai keterampilan, latihan, dan pekerjaan agar mereka dapat meningkatkan penghasilan bersamaan dengan diberikannya berbagai barang konsumsi jangka pendeknya untuk menunjang kerja, fasilitas-fasilitas angkutan, tempat tinggal, dan sebagainya. Kahf menyebutkan bahwa tidak ada ketentuan khusus sama sekali bahwa pendistribusian dana-dana zakat harus secara tunai, dan juga tidak ada ketentuan khusus bahwa zakat harus diwujudkan dalam bentuk barang-barang konsumsi seperti bahan makanan atau pembagian zakat secara langsung dalam pengertian barang-barang atau jasa nyata. Satu-satunya pembatasan yang dapat diketahui oleh setiap orang adalah bahwa zakat dilaksanakan karena telah melampaui tingkat minim yang dibebaskan (dari pembayaran zakat), dengan ketentuan bahwa "orang yang mampu membayar zakat tidak dibenarkan menerimanya". Tingkat minim yang dibebaskan dari zakat itu dinyatakan dalam pengertian persediaan atau harga yang tetap dimiliki selama lebih dari setahun

Zakat meningkatkan pendapatan orang-orang miskin. Karena rendahnya pendapatan mereka, tambahan pendapatan tersebut akan digunakan untuk membeli barang-barang dan jasa-jasa pokok sehingga meningkatkan permintaan agregat terhadap barang-barang dan jasa-jasa pokok. Meningkatkan permintaan aggregat ini akan menarik peningkatan investasi. Di sisi lain zakat juga secara agregat mendorong peningkatan tabungan dan investasi.

Dalam norma-norma Islam, zakat dianggap dapat memberikan efek positif terhadap nilai investasi dengan asumsi bahwa perubahan ini benar-benar terjadi dan dilingkungan investasi yang sesuai benar-benar ada. Bagi hasil berdasarkan nisbah yang adil antara pemberi modal dan pengusaha dianggap akan dapat mengarahkan alokasi sumber daya menjadi lebih efisien. Dengan dihilangkanya salah satu sumber pokok dari ketidakpastian dan ketidakadilan yang mempengaruhi keputusan investasi, pengusaha akan lebih mudah untuk melakukan pengambilan keputusan penabung menjadi pengusaha, memungkinkan resiko bisnis terdistribusi lebih merata dengan jalan memperbaiki iklim investasi.

Cara lain pendistribusian zakat dilakukan dengan memberikan bantuan modal usaha bagi para mustahiq/kaum dhuafa. Akses permodalan terhadap kelompok usaha yang dimiliki kaum dhuafa ini masih sangat terbatas, berbeda dengan akses permodalan bagi usaha besar yang melimpah ruah. Sehingga, diperlukan sejumlah alternatif sumber pendanaan yang bisa mengangkat pertumbuhan usaha mikro ini.

Pendistribusian zakat dengan cara ini akan memberikan dua efek yaitu meningkatkan penghasilan mustahiq/kaum dhuafa, dan juga akan berdampak pada ekonomi secara makro. Usaha yang dilakukan tersebut merupakan usaha yang meningkatkan sektor riil, menggerakkan pertumbuhan dan aktifitas perekonomian. Hal ini sangat erat kaitannya dengan daya saing kompetitif dan komparatif suatu bangsa. Ukuran produktifitas suatu bangsa dapat dilihat dari kemampuan sektor riilnya dalam menghadapi persaingan yang semakin ketat. Di sinilah pentingnya menjadikan ZIS sebagai instrumen permodalan bagi usaha kaum dhuafa ini. 


\section{Kesimpulan}

Zakat menempati kedudukan yang sangat penting dalam Islam. Oleh karena itu dimasukkan diantara lima pilar agama Islam yaitu kedua setelah shalat. Perintah untuk menunaikan shalat dalam Al Quran selalu diikuti dengan acuan pada zakat dan dengan penekanan yang sama.

Salah satu tujuan dari zakat adalah untuk mempersempit perbedaan ekonomi di masyarakat sampai batas yang serendah mungkin. Hal ini untuk menjaga perbedaan ekonomi di kalangan masyarakat dalam batas yang adil dan wajar sehingga orang kaya tidak tumbuh semakin kaya dan yang miskin semakin miskin.

Islam tidak hanya menjadikan zakat sekedar pungutan wajib, akan tetapi sebuah ketentuan negara, sebab zakat dikumpulkan dan didistribusikan oleh pemerintah. Al Quran dengan jelas mengindikasikan bahwa lembaga zakat harus dibina, diorganisir dan dilestarikan oleh pemerintah.

Zakat dipungut atas modal dari beraneka ragam jenis yang terkumpul sebagai suatu kelebihan pada tiap akhir tahun. Nabi saw. bersabda: "Tidak ada zakat atas kekayaan sebelum berlangsung setahun". Penerapan hal ini dapat mempersempit kesenjangan sosial, diantaranya dengan pengembangan terhadap sektor riil.

Orang yang mengingkari zakat, maka ia adalah kafir karena telah mengingkari perkara agama. Barang siapa yang mengakui zakat tetapi ia tidak mau membayarnya maka ia adalah orang Islam yang bermaksiat, melakukan dosa besar dan diancam oleh Allah swt. dengan siksaan yang amat berat, sesuai dengan surat At Taubah ayat 34-35 di dalam Al Quran.

\section{DAFTAR PUSTAKA}

Abdullah al-Mushlih, Shalah ash-Shawi, Fikih Ekonomi Keuangan Islam, edisi terjemahan, Jakarta: Darul Haq, 2004.

Afzalurrahman, Muhammad Sebagai Seorang Pedagang, Jakarta: Yayasan Swarna Bhumy, 1997.

Karim, Adiwarman, Ekonomi Islam Suatu Kajian Ekonomi Makro, Jakarta: IIIT Indonesia, 2002.

Mannan, Muhammad Abdul, Teori Dan Praktek Ekonomi Islam, edisi terjemahan, Yogyakarta: PT. Dana Bhakti Wakaf, 1997.

Qardawi, Yusuf, Peran Nilai Dan Moral Dalam Perekonomian Islam, edisi terjemahan, Jakarta: Robbani Press, 2001. 
, Hukum Zakat, edisi terjemahan, cetakan ke tujuh, Jakarta: Litera Antar Nusa, 2004.

Shahatah, Hasayn, Akutansi Zakat Panduan Praktis Penghitungan Zakat Kontemporer, edisi terjemahan, Jakarta: Pustaka Progressif, 2004.

Suprayitno, Eko, Ekonomi Islam; Pendekatan Ekonomi Makro Islam dan Konvensional, Jakarta: Graha Ilmu.

Zuhdi, Masjfuk, Masail Fiqiyah; Kapita Selekta Hukum Islam, Jakarta: CV. Haji Masagung, 1993.

Ratu Humaemah, dosen pada Fakultas Syari'ah dan Ekonomi Islam IAIN Sultan Maulana Hasanuddin Banten. 